they are now receiving, and that they should be conserved and utilized to a fuller extent.

JosePH GRINnELL,

Tracy I. Storer

UNIVERSity OF CALIFORNIA

\section{THE REVIVAL OF INTEREST IN BIRD ANATOMY AT THE UNITED STATES NATIONAL MUSEUM}

Very well do I remember when the foundation was laid for a department of comparative anatomy at the United States National Museum. It took place some time along in the early eighties. when Professor Baird's splendid régime was at its height and zoological work was at its best at the Smithsonian Institution. My early papers on the osteology of birds had appeared in Hayden's Twelfth Annual of the U. S. Geological and Geographical Survey of the Territories, and, owing to a fulfilment of a promise made by the then surgeon-general of the army, I found myself in the position of curator of the department of comparative anatomy at the old Army Medical Museum on Tenth Street in Washington. Naturally, I desired to follow up my work on the osteology of birds and upon vertebrate anatomy generally. This impulse led me to obtain Professor Baird's permission to examine what the collections at the National Museum contained in the way of material for descriptive purposes, and to look into the matter of the possibility of publishing researches along such lines.

Professor Baird was a man who took an intense personal interest in the labor of all his curators, and it was his habit every day, when he could afford the time to do so, to make a round of the institution for the purpose of encouraging them in their investigations and to learn whether there was anything, in any particular case, that a curator needed to push his investigations forward. He no sooner noticed my interest in bird anatomy than he opened up the way to make it count for science, and for the advancement of work in that particular field. He immediately established a base for such operations by founding a new position for those not on the regular museum staff, but who were devoting a large share of their time to scientific investigation, with the view of publishing the results of their studies. The late distinguished Dr. Theodore Nicholas Gill and myself were the first two zoologists appointed by Professor Baird to become co-workers under him as "associates in zoology" on the staff of the institution. Shortly after this event, I undertook to examine the collection there of such material as illustrated the morphology of birds. The alcoholic collection contained many specimens of great value; but what interested me most at that time was the collection of bird skeletons. This consisted of a very remarkable, not to say heterogeneous, lot of avian skeletons, none of which were scientifically prepared. Many were roughed out; a large array of them had been cleaned up by the "sand fleas" of the seas that wash our Alaskan possessions, and, finally, not a few of them were sterna of birds saved by bird collectors all over the country while skinning specimens for their collections. To show how valuable some parts of the material were, I may say that, in one little pasteboard box, I found the original chicken skulls used by Charles Darwin in Volume One of his "Animals and Plants Under Domestication" (Figs. 34, 35 and 36), they evidently having been presented to the Smithsonian either by himself or by Mr. Tegetmeier. (How long they had been in that little box I do not know; at this writing they have been placed in a special case in one of the exhibition halls of the new National Museum!)

A great mass of these skeletons had been collected by our northern explorers, as Dall, Elliott, Bean, Nelson, Turner and others, and were in a fairly good condition. All this material was in "original packages," that is, in any old receptacle the collector could lay his hands upon in the field-chiefly empty cigarboxes, all sorts of pasteboard boxes, boxes that had held ammunition for collectors, etc. All had been stored away and was covered with the dust of time. However, I gave the lot a preliminary going over, and Professor Baird promptly assigned to my department-the department of comparative anatomy-an old 
lady with a feather duster, requesting me to make known to him anything else I might require. My assistant immediately started in with the duster, and the material was brought to light. A request of mine for an assorted lot of cardboard boxes was favorably considered early in my work; in due course the collection of bird skeletons was boxed, the specimens labeled, and the whole made accessible for the use of students.

At this stage of the proceedings a board appointed by the government found me unfitted for promotion (Doctor Coues was also at work in the Smithsonian Institution), and I was ordered to New Orleans. Dr. Lucas succeeded me; and through his splendid energy and genius, the department of comparative anatomy was placed on a sound basis, with a wealth of material of all kinds, elegantly exhibited and cased. Indeed it was, at the close of his régime, the envy and admiration of all the scientific institutions in the world that knew anything about the department. After Dr. Lucas's connection with the National Museum was severed, and I had been, upon second thought of the government, found fitted for promotion and duly ordered west, the department of comparative anatomy seemed to slowly dwindle away, finally being split up among the various divisions of the National Museum. Eventually the bird alcoholics and skeletons drifted into Professor Ridgway's division, and, through no fault of his, a long period of statu quo ante lucasum set in.

During my seven years' study of crime and human psychology and morphology in New York City I wrote but few papers on the osteology of birds, and these were based principally on material sent me by the Bureau of Science at Manila and the Zoological Society of London. Then, when I returned to Washington to live, my work in vertebrate anatomy was more actively taken up, as I had determined it should be before the sojourn in New York was decided upon. At the end of four or five years or more, when my published memoirs in that field began to run up into the dozens, and the figures illustrating them into many hundreds, I found that I was deeply in- debted to the.United States National Museum for the loan, at different times, of a great number of bird skeletons used in that particular field of my work. The assistance rendered me by that institution has proved invaluable, and the aid given by Professor Ridgway, and by Dr. Richmond and his assistants, has been and is most thoroughly appreciated.

For a year or more past I have observed, without commenting upon the fact, that there has been a slow but steady improvement upon the former condition of things in the section containing the boxed collection of bird skeletons. Notwithstanding his arduous duties as assistant curator of the division of birds, Dr. Richmond has made a requisition for a series of cases to contain the collection, and these are now in use in a fairly convenient place in the department. A “cleaning up" gradually followed, and a raking together of all the bird skeletons that were in various rooms in the museum. These were placed in trays, to be eventually cleaned and boxed. But what was to be done with them? Professor Ridgway, deep in completing his great work on "The Birds of North and Middle America," could not, even had he wished to do so, think of giving the matter a moment's attention, and Dr. Richmond has as much as he can possibly handle by attending to the affairs of one of the most important departments of the museum-the division of birds, with its enormous collection of bird skins; with its library and correspondence, and with other duties too numerous to mention.

At this juncture, through fortunate circumstances, Mr. Alex. Wetmore, of the Biological Survey, became interested in the matter, and through a mutual cooperation of all concerned, he arranged to put the collection of bird skeletons into the various cases supplied for them, and to settle the material in place as best he could, after his duties at the survey were over for the day. This has been accomplished as far as could be expected under the circumstances, and Mr. Wetmore has emphasized the interest he has taken in the new order of things by publishing a number of 
brief though important contributions to bird anatomy.

The interest of the veteran ornithologist, Mr. Oberholser, has also been aroused, and therefore it is likely that additional good results will be forthcoming.

Thus matters seem to stand at the present time, and there is hardly any room for doubt but what an added interest is being taken in this most important branch of biology. If it be genuine and progressive, American science is to be heartily congratulated; should it lead to the appointment of a curator of the department of bird anatomy-of one who understands the aims and needs of such a department and who has the energy to make it in time what it should be, I feel sure that there are congratulations in waiting when such a happy sequel materializes.

Personally, I have always regretted that the division of comparative anatomy of the U.S. National Museum was dissolved, as this was a prima facie evidence of a stage of decadence setting in, in a very vital part of the scientific organism. It should be put on foot again in full force, and brought up to the standard where it properly belongs. We are terribly wasteful in such matters; the absence of a division of comparative anatomy in the United States $\mathrm{Na}$ tional Museum can only be equaled by the present and corresponding deficiency in the matter of a prosectorial department connected with the National Zoological Park at Washington, where animals frequently die and no attempt is made whatever to examine and report upon their anatomy.

America is coming to the front in many things now besides in what the dollar means, and it should be the aim of science to look well to it that this field is brought properly into line.

WASHINGTON, D. C.

\section{SCIENTIFIC NOTES AND NEWS}

Dr. Percival Lowell and Professor F. Schlesinger have been elected honorary fellows of the Royal Astronomical Society of Canada.

Professor S. W. Williston, of the department of geology and paleontology of the Uni- versity of Chicago, has been appointed director of the Walker Museum.

Professor J. G. SANDERs has resigned as state entomologist of Wisconsin to become economic zoologist of Pennsylvania. His work at Harrisburg begins on September 16, 1916. Dr. S. B. Fracker has been appointed acting state entomologist of Wisconsin by the commissioner of agriculture, and will have charge of the work of the state entomologist's office until a successor to Professor Sanders is appointed.

C. H. HadLex, JR., of the department of entomology of Cornell University, has been appointed extension entomologist at the Pennsylvania State College.

Dr. RoBert Armstrong-Jones has retired from the post of medical superintendent of the London County Lunatic Asylum. A special pension has been awarded to him on the recommendation of the Asylums Committee of the London County Council.

Dr. Linsly R. Williams, deputy commissioner of the New York State department of health, has been appointed by Governor Whitman to conduct an investigation into the proposed building of a garbage disposal plant for New York City on Staten Island.

The Mississippi Valley. Conference on tuberculosis will be held at Louisville, Ky., from October 4 to 6 , under the presidency of Walter D. Thurber, of Chicago.

Mr. WeLLington Jones, of the department of geography, University of Chicago, is traveling in eastern Asia in preparation for the giving of courses in the geography of Asia.

THe faculty of medicine of the University of Toronto, which suffered from the enlisting of professors for service in connection with the University Base Hospital, will be strengthened by the return of Dr. John J. MacKenzie, professor of pathology and bacteriology, and Dr. Benjamin P. Watson, professor of obstetrics and gynecology.

During July the botanical laboratory of the Purdue Experiment Station at Lafayette, Ind., had the services of Dr. Frank D. Kern and Professor C. R. Orton, of the Pennsylvania 